\title{
Effect of early nutrition on carcass and meat quality of young goats under milk production systems
}

\author{
A. Argüello, N. Castro, D. Sánchez-Macías and J. Capote
}

\subsection{Abstract}

Goat kids in intensive dairy goat farms are usually reared on milk replacers, due to farmers' desire to use all the milk for commercial purposes or cheese-making. In this chapter, growth, carcass and meat quality characteristics of goat kids fed milk replacers are studied in depth in comparison with kids reared naturally on goat milk.

\subsection{Introduction}

Different management methods have been proposed for goat kid rearing on dairy goat farms. These include natural suckling (NS), restricted natural suckling (RNS), ad libitum artificial rearing (ALAR) on milk replacers and restricted artificial rearing (RAR). These are summarized as follows:

- The NS system implies that kids remain with their dams from birth until the end of the suckling period with free access to goat milk $24 \mathrm{~h}$ a day.

- $\quad$ RNS is a system in which kids have access to their dams for a limited period of time per day.

- ALAR implies that kids are hand-fed colostrum during the first 2 days after birth. After the colostrums feeding period, the kids usually are accommodated in artificial rearing pens with at least $0.3 \mathrm{~m}^{2}$ floor space per kid. Centrally heated pens have a temperature of around $20^{\circ} \mathrm{C}$. The animals are trained to suckle from an artificial teat fitted to a unit for feeding liquid diets. The milk replacer is continuously mixed and offered ad libitum on a $24 \mathrm{~h}$ basis.

- Under the RAR system, kids are reared as for the ALAR group except that milk replacers are made available twice a day for a limited period of time.

Goat milk and milk replacers differ in composition. The protein source of milk replacers is often milk protein concentrates and whey proteins (Beserra et al., 2003). The casein content of milk replacers is lower than in goat milk, which may produce some problems with curd formation in the kid abomasum (Sanz Sampelayo et al., 1990). Hashimoto et al. (2007) included soy as a protein source in milk replacers, but the effects on growth and meat quality are yet to be clearly defined. Carbohydrates are higher in milk replacers due to the overall lactose content. The main raw components in milk replacers are cow skimmed milk and cheese whey, and both are very rich in lactose. A high lactose content in milk replacers has been related to osmotic diarrhoea in kids (Argüello et al., 1999). Some experiments have been carried out using starch as a raw material in milk replacers (Nitsan et al., 1990), but diarrhoea was a major problem. A major difference in chemical composition between goat milk and milk replacers is also the fat source. Milk replacers are based on cow skimmed milk and cheese whey, and both ingredients have a low fat content. Therefore, vegetable fats are added to milk replacers as the main fat source. These include mainly palm or coconut oils. Bañón et al. (2006) recently reported substantial differences in fatty acid composition between goat milk and milk replacers. The main fatty acids in goat milk are C16:0 (30\%), C18:1 (22\%) and C18:0 (14\%), whereas in milk replacers they are C12:0 (29\%), C16:0 (23\%) and C18:1 (16\%). New advances in milk replacer formulations are currently under way. Tacchini et al. (2006) reduced the use of cow milk to $15 \%$, and our group is introducing seaweed into formulations with encouraging preliminary results. 


\subsection{Goat kid growth under goat milk or milk replacer diets}

The goat is an important source of meat in Africa, Asia and the Far East. It is now emerging as an alternative and attractive source of meat in other parts of the world. With milk goat breeds, kids are usually reared on milk replacers, so that all milk produced can be sold as fresh milk or processed into dairy products as cheese or yogurt. Young kids have to be routinely fed milk replacers.

\subsubsection{Growth curves}

Growth in farm animals in general, and goats in particular, is usually represented by an exponential curve. However, observations during the first month of life have shown a better statistical fit to a linear regression (Argüello et al., 2004).

Growth curves of kids reared during the first month of life under NS, ALAR and RAR systems are shown in Fig. 14.1 (Argüello et al., 2004). NS kids have a significantly higher average daily gain (ADG) than ALAR and RAR kids (Pérez et al., 2001; Argüello et al., 2004), and ALAR kids have a significantly higher ADG than RAR kids (Argüello et al. 2004). The higher ADG in NS kids is caused by the higher digestibility of components in goat milk than in milk replacers because the goat milk curd stays longer in the abomasum than the milk replacer curd (Sanz Sampelayo et al., 1990; Baumrucker and Blum, 1993). Baumrucker and Blum (1993) found that dams' milk has a growth promoter that is not present in milk replacers, which could explain the higher ADG in NS kids. NS kids growth rates ranged from 140 to $200 \mathrm{~g}$ /day in different breeds such as Majorera (Argüello et al., 2004), Verata (Fariña et al., 1989) and Damascus (Louca et al., 1977). Some authors have attributed the higher growth rate to a higher feed intake capacity in kids raised ad libitum (Sanz Sampelayo et al., 1987; Yan et al., 1993).

\section{Fig. 14.1 near here.}

There are many factors that affect growth curves of farm animals, including birth weight, feed conversion efficiency and RNS, each of which is discussed in more detail.

\section{Birth weight}

Birth weight has an important effect on the first month's growth pattern for goat kids (Argüello et al., 2004). Table 14.1 shows the results for Majorera goat kids where the Pearson correlation coefficients between birth weight and weight at $n$ days were statistically significant $(P<0.01)$ throughout the first 28 days of life for all groups. While the significance of the correlation coefficients observed with the ALAR and RAR methods lasted throughout the whole experiment, in the NS method the correlation lasted only until day 28 . This behaviour is the opposite of what we expected, as the constant availability of food should have minimized the effect of birth weight.

\section{Table 14.1 near here.}

\section{Feed conversion efficiency}

From a financial point of view, it is also necessary to evaluate the feed conversion efficiency (FCE), which is a measure of an animal's efficiency in converting feed mass into increased body mass. Argüello (2000) reported similar FCEs for both male and female animals, with higher FCE values observed at the beginning of the experiment compared with the final period (Fig. 14.2). Tejón et al. (1995) reported FCE levels of 1060.19 and $1115.11 \mathrm{~g} / \mathrm{kg}$ for males and females, respectively, in Guadarrama goat kids reared by artificial rearing for 0-21 days. The differences displayed between initial and final FCE levels are probably due to the lesser development of the digestive tract in kids at an early age. This becomes more evident in terms of milk assimilation and transformation as the animal grows older. The results obtained for FCE in males and females indicate that females are more efficient in terms of milk replacer transformation. Nevertheless, such differences are slight and are probably due to the greater voracity of males, which makes them tend to consume greater amounts of feed regardless of age.

Fig. 14.2 near here. 


\section{Restricted natural suckling}

In special circumstances, kids are reared under RNS management. When the milk is highly valuable, farmers try to minimize the amount of milk used for feeding kids and allow the kids to access their mothers for only a few hours a day. This system of management reduces the ADG in kids (Genandoy et al., 2002) compared with NS management due to the lower milk intake. Therefore, RNS is not an adequate management system for meat production and must be recommended only when milk has a high price.

\subsection{Effect of the diet (goat milk or milk replacers) on kid carcass quality}

Goats are ruminant animals that produce useful products such as fibre, meat, milk and leather. In some regions of the world such as southern Europe, goats have been selected primarily for milk production (Harvey and Rigg, 1964). In such systems, few goats are raised for meat production as the major selection criterion in regions where milk production is the primary focus. Kid carcasses from dairy goats have little fat (Kirton, 1988). Traditionally, in non-specialized dairy goat herds, goat kids are reared with their dams, which results in reduced milk yield and thus less milk for cheese manufacturing. Therefore, goat keepers remove the kids from their dams very early post-natally (15 days of age; 5-6 kg live weight). These kids are then harvested for meat. Unfortunately, carcasses from these kids are very light in weight $(\sim 3 \mathrm{~kg})$ and therefore have little saleable meat. Furthermore, consumers in Mediterranean countries and others regions (e.g. Canary Islands) prefer meat from kids that have only been fed milk. All these factors contribute to the production of a very light live weight of kids at slaughter and carcasses with low meat quality and yield, resulting in goat keepers not earning significant financial profits.

\subsubsection{Body weight, carcass yield and offal}

Losses in goat kid carcasses due to chilling are not affected by diet (goat milk vs milk replacers) according to Argüello et al. (2007). In reference to carcass yield, some authors (Argüello et al., 2007) did not observe differences between animals fed goat milk or milk replacers due to lack of differences in nutritive characteristics between diets. Table 14.2 shows weights and carcass yield in goat kids fed goat milk or milk replacers (Argüello et al., 2007).

\section{Table 14.2 near here}

Argüello et al. (2007) studied the influence of diet on offal components in kids (Table 14.3). There were no significant effect of diet on the percentage of blood, skin, feet, gastrointestinal tract full and empty, gastrointestinal content, liver, urinary bladder, testicle plus penis, spleen, head, lungs plus trachea, heart and thymus of the live weight at slaughter. However, the weight of the right kidney was significantly higher in kids fed with milk replacers.

Table 14.3 near here

\subsubsection{Carcass conformation}

Argüello et al. (2007) studied carcass conformation measurements and indices in Majorera goat kids fed goat milk or milk replacers. These included: width between hips $(\mathrm{G})$, depth at 6 th rib (Th), carcass length $(\mathrm{L})$, leg length (F), chest width (Wr), hips perimeter (B), long leg compact indices (G/F and B/F), cold carcass weight $(\mathrm{CCW})$ and carcass compactness index (CCW/L) (Table 14.4 and Fig. 14.3). These authors found differences $(P<0.01)$ between diets for $\mathrm{L}$ and $\mathrm{F}$ measurements. Rearing in small pens (milk replacer diet) could be the reason for these little differences found between kids on different diets. There were no significant differences between diets in G, WR, B and TH measures and CCW/L, G/F and B/F indices. There were significant interactions between diet and live weight at slaughter for $\mathrm{L}$ and $\mathrm{F}$ measures and $\mathrm{CCW} / \mathrm{L}, \mathrm{G} / \mathrm{F}$ and $\mathrm{B} / \mathrm{F}$ indices. When kids' live weight at slaughter was $6 \mathrm{~kg}$, higher $\mathrm{CCW} / \mathrm{L}$ values in kids on the milk replacer were found, due to these animals being older.

\section{Table 14.4 near here.}




\section{Fig. 14.3 near here.}

\subsubsection{Primal cut distribution}

Some authors (Argüello et al., 2007) found no differences in primal cut distribution in kids fed goat milk or milk replacers (Table 14.5). However, Sanz Sampelayo et al. (1985) found differences in lumbar rib percentages $(\sim 2 \%)$ between kids fed goat milk and kids fed milk replacers. These differences were probably a result of using different carcass jointing procedures.

\section{Table 14.5 near here}

\subsubsection{Tissue composition}

Argüello et al. (2007) studied the effect of diet (goat milk vs milk replacers) on tissue composition of kid carcasses (Table 14.6). There were significant effects of diet on subcutaneous, intermuscular and total fat in carcass and ribs, with the differences being higher in animals fed goat milk. Shoulder, long leg and flanks had lower percentages of intermuscular and total fat in kids fed milk replacers. There were no differences in fat content in neck. Morand-Fehr et al. (1986) previously reported similar results. They attributed this to a higher amount of fat fed in the NS system than in kids fed with milk replacers. The carcass total fat contents were lower than those reported by Gutiérrez et al. (1995) but were closer to those obtained by Colomer-Rocher et al. (1992). In the same breed, Argüello et al. (1997a,b,c) found that, while the amount of milk replacers increased, the total carcass fat percentage also increased. The bone and muscle tissue percentages did not differ as a result of diet.

Table 14.6 near here.

\subsection{Effect of diet (goat milk or milk replacers) on kid meat quality}

The goat population in the world comprises four major types of goat: fibre goats (e.g. angora, cashmere), dairy goats (e.g. Saanen, Toggenburg and Nubian), meat goats (e.g. Boer) and feral goats (Naudé and Hofmeyr, 1981). The world's goat population was around 870 million in 2009, with annual meat production of around 4.9 million tonnes (FAOSTAT, 2010). Consumers' preference for goat meat varies around the world. For instance, in India, the local community specifically seeks meat from mature goats, whereas in France and Latin America, meat from young milk-fed kids is considered a traditional delicacy. The acceptability of meat is greatly influenced by local custom and preference, so it is not possible to apply a universal standard for the quality of goat meat (Naudé and Hofmeyr, 1981).

\subsubsection{Physical attributes}

Physical attributes of meat quality include: $\mathrm{pH}$, colour, tenderness and water-holding capacity. Some authors have studied the effect of diet (goat milk or milk replacers) on the meat quality of young goats (Argüello et al., 2005; Bañón et al, 2006). They did not find significant effects of diet on pH value or lightness, except for some slight differences in chroma values (a less intense red colour) (Tables 14.7, 14.8 and 14.9). Meat tenderness is considered one of the most important attributes in terms of consumer satisfaction. Diet significantly affected shear force values in the semimembranosus and triceps brachii muscles (Tables 14.8 and 9) with animals fed milk replacers having greater shear force values than animals fed goat milk. A similar trend was also observed for the longissimus dorsi muscle. These differences could be attributed to the fact that the animals were older and had consumed greater amounts of starter feed. This is in agreement with reports by Pisula et al. (1994), who found statistical differences between kids slaughtered at $16 \mathrm{~kg}$ live weight and exclusively fed milk replacers and those that had consumed starter feed (35.7 vs $42.6 \mathrm{~N}$, respectively). The values obtained for water-holding capacity ranged between $0.31 \mathrm{~g}$ $(6.2 \%)$ and $0.72 \mathrm{~g}(14.4 \%)$. The $\mathrm{pH}$ value and protein content play a fundamental role in the greater levels 
of expelled juice in animals fed goat milk (Argüello et al., 2005). The average pH value for animals fed goat milk replacers after chilling was 5.65, while kids receiving milk replacers had an average $\mathrm{pH}$ value of 5.70 .

\section{Table 14.7 near here \\ Table 14.8 near here \\ Table 14.9 near here}

\subsubsection{Chemical composition and muscle characteristics}

Argüello et al. (2005) reported protein values of $\sim 17-20 \%$ in goat kids, which resembles that of very young animals, as well as low muscle fat $(0.84-1.26 \%)$. Fat is a late-growing body tissue, and in goats it is deposited in the more viscera than in other animals (Chilliard et al., 1981). The type of diet did not have a significant effect on the chemical composition of kid carcasses (Argüello et al., 2005). This is in accordance with the observations of Mueller et al. (1985) using kids of similar weights and feed types. In contrast, Bañón et al. (2006) reported higher moisture in kids fed goat milk or milk replacers (77 and 76\%, respectively) and less protein in kids fed milk replacers. Collagen percentages and solubility were not affected by diet (Argüello et al., 2005; Bañón et al., 2006). Diet did not affect muscle fibre areas (Tables 14.7, 14.8 and 14.9), following the muscle fibre classification of Argüello et al. (2001).

\subsubsection{Fatty acid percentages}

Bañón et al. (2006) investigated diet effects on fatty acid composition in perirenal fat. The major fatty acids were C18:1, C16:0 and C18:0. These authors reported higher percentages in goat milk-fed kids than in artificially reared kids for the fatty acids $\mathrm{C} 10: 0, \mathrm{C} 14: 0, \mathrm{C} 15: 0, \mathrm{C} 16: 0$ and C18:0. In contrast, the goat milkfed kids had lower values of C12:0, C16:1, C17:0, C18:1, C18:2, C18:3, C20:0 and C:20:4. The main fatty acids in kids receiving goat milk were $\mathrm{C} 16: 0, \mathrm{C} 18: 1$ and $\mathrm{C} 14: 0$, and the ratio of saturated:unsaturated fatty acids was 2.27. In animals receiving milk replacers, the main fatty acids were $\mathrm{C} 18: 1, \mathrm{C} 16: 0$ and C18:0, and the saturated:unsaturated ratio was 0.94. Together with previous results, Bañon et al. (2006) thus demonstrated a strong effect of diet on fatty acid content.

\subsubsection{Sensorial quality}

Bañón et al. (2006) observed that the goat milk or milk replacer diet had pronounced effects on the sensory quality of cooked meat. The milk replacer diet gave cooked meat a more intense characteristic odour and flavour, more tenderness and increased juiciness.

\subsection{Conclusions}

Rearing goat kids with milk replacers has significant repercussions on their growth, carcass and meat quality. Goat kids fed milk replacers grow at a slower rate and have leaner carcasses than kids fed goat milk. The meat from kids fed milk replacers is characterized by a more intense colour. Substantial differences have also been reported in fatty acid profile. However, although the kids produced using the two diets differ, rearing goat kids on intensive dairy goat farms on milk replacers is more profitable if there is large enough price margin between goat milk and milk replacers. 


\section{References}

Argüello, A., Arjona, J., Piñán, J., Ginés, R., Capote, J. and López, J.L. (1997a) Características cárnicas de cabritos de la Agrupación Caprina Canaria (ACC: variedad tinerfeña) criados con lactancia artificial. In: XXII Jornadas Científicas de la Sociedad Española de Ovinotecnia y Caprinotecnia, Tenerife, Spain, pp. 407-415.

Argüello, A., Ginés, R., Afonso, J.M. and López, J.L. (1997b) Utilización de yogur en la lactancia artificial de cabritos de la Agrupación Caprina Canaria (ACC). In : XXII Jornadas Cientificas de la Sociedad Española de Ovinotecnia y Caprinotecnia, Tenerife, Spain, pp. 423-430.

Argüello, A., Rodríguez, M., Darmanin, N., Afonso, J.M., Capote, J. and López, J.L. (1997c) Características cárnicas de cabritos de la Agrupación Caprina Canaria (ACC) criados con lactancia tradicional (media leche). In : XXII Jornadas Científicas de la Sociedad Española de Ovinotecnia y Caprinotecnia, Tenerife, Spain, p. 417.

Argüello, A., Ginés, R. and López, J.L. (1999) A note on yogurt utilisation in artificial rearing of kids. Journal of Applied Animal Research 15, 165-168.

Argüello, A. (2000) Lactancia artificial de cabritos, encalostrado, crecimiento, calidad de la canal y de la carne. $\mathrm{PhD}$ thesis, Las Palmas de Gran Canaria University, Spain.

Argüello, A., López-Fernández, J.L. and López-Rivero, J.L. (2001) Limb myosin heavy chain isoprotein and muscle fiber types in the adult goat (Capra hircus). Anatomical Record 264, 284-293.

Argüello, A., Castro, N. and Capote, J. (2004) Growth of milk replacer kids fed under three different managements. Journal of Applied Animal Research 25, 37-40.

Argüello, A., Castro, N., Capote, J. and Solomon, M. (2005) Effects of diet and live weight at slaughter in kid meat quality. Meat Science 70, 173-179.

Argüello, A., Castro, N., Capote, J. and Solomon, M.B. (2007) The influence of artificial rearing and live weight at slaughter on kid carcass characteristics. Journal of Animal and Veterinary Advances 6, 20-25.

Bañón, S., Vila, R., Price, A., Ferrandini, E. and Garrido, M.D. (2006) Effects of goat milk or milk replacer diet on meat quality and fat composition of suckling goat kids. Meat Science 72, 216-221.

Baumrucker, C.R. and Blum, J.R. (1993) Secretion of insulin-like growth factors in milk and their effect on the neonate. Livestock Production Science 35, 49-74.

Beserra, F.J., Bezerra, L.C.N.M., Silva, E.M.C. and Silva, C.E.M. (2003) Influence of the replacement of cow milk by goat milk cheese whey on meat composition carcass characteristics of three cross suckling kids. Ciencia Rural 33 , 929-935.

Borghese, A., Terzano, G.M. and Bartocci, S. (1990) La produzione del capretto negli allevamenti intensivi. 6. Caratteristiche della carcassa e della carne in soggetti Saanen e Camosciata dellet alpi di 35 e 50 giorni di eta. Zootecnia e Nutrizione Animale 16, 167-178.

Chilliard, Y., Sauvant, D., Bas, P., Pascal, G. and Morand-Fehr, P. (1981) Importance relative at activités métaboliques des different tissus adipeux de la chévre laitiére. Nutrition and systems of goat feeding. ITOVIC-INRA, Paris, France, 90-100.

Colomer-Rocher, F., Kirton, A.H., Mercer, G.J.K. and Duganzich, D.M. (1992) Carcass composition of New Zealand Saanen goats slaughtered at different weights. Small Ruminant Research 7, 161-193.

FAOSTAT (2010). Caprine heads and meat production. Live animals and livestock primary. US Food and Agriculture Organization $<$ http://faostat.fao.org/site/339/default.aspx $>$.

Fariña, J., Martín, L., Rodríguez, P., Rojas, A., Rota, A. and Tovar, J. (1989) Estudio de los chivos veratos. Periodo de amamantamiento. Archivos de Zootecnia 38, 127-139.

Genandoy, H., Sahlu, T., Davis, J., Wang, R.J., Hart, S.P., Puchala, R. and Goetsch, A.L. (2002) Effects of different feeding methods on growth and harvest traits of young Alpine kids. Small Ruminant Research 44, 81-87.

Gutiérrez, M.J., Peña, F., Rodero, E. and Herrera, M. (1995) Producción ovina y caprina. In: XX Jornadas Cientificas de la Sociedad Española de Ovinotecnia y Caprinotecnia, Madrid, Spain, pp. 421-425.

Harvey, D. and Rigg, J.C. (1964) Some aspects of goats as livestock. Nutrition Abstracts and Reviews 34, 641-645.

Hashimoto, J.H., Alcalde, C.R., Silva, K.T., Macedo, F.A.F., Mexia, A.A., Santello, G.A., Martin, E.N. and Matsushita, M. (2007) Caracteristicas de carcaça de caprinos Boer x Saanen confinados recebendo rações com casca do grão de soja em substituição ao milho. Revista Brasileira de Zootecnia 36, 165-173.

Kirton, A.H. (1988) Characteristics of goat meat including carcass quality and methods of slaughter. In: Goat Meat Production in Asia. Proceedings of an International Workshop in Tando Jam, Pakistan. International Development Research Centre, Ottawa, Canada, pp. 87-99.

Louca, A., Economides, S. and Hancock, J. (1977) Effect of castration on growth rate feed conversion efficiency and carcass quality in Damascus goats. Animal Production 24, 387-391.

Morand-Fehr, P., Bas, P., Schmidely, P. and Hervieu, J. (1986) Qualité des produits chez les ovins et les caprins. In: 10 Journées de la Recherche Ovine et Caprine, INRA, pp. 236-247. 
Mueller, R., Steinhart, H. and Scheper, J. (1985) Carcass composition and meat quality of kids. Influence of feeding. Fleischwirtschaft 65, 194-196.

Naudé, R.T. and Hofmeyr, H.S. (1981) Meat Production. In: C. Gall (ed.) Goat production. Academic Press, London, UK, pp. 285-307.

Nitsan, Z., Golan, M. and Nir, I. (1990) Utilization of raw or heat-treated starch fed in liquid diet to preruminants 1. Kids. Small Ruminant Research 3, 325-339.

Pérez, P., Maino, M., Morales, M.S. and Soto, A. (2001) Effect of goat milk and milk substitutes and sex on productive parameters and carcass composition on Creole kids. Small Ruminant Research 42, 87-93.

Pisula, A., Slowinski, M., Pawlowski, P., Bidwel-Porebska, K., Piotrowski, J. (1994) Chemical composition, physicchemical properties and organoleptic quality of 'milk' kid meat reared to $16 \mathrm{~kg}$ of body weight. Gospodarka-Miesna $46,15-17$.

Sanz Sampelayo, M.R., Muñoz, F.J., Lara, L., Anguita, T., Gil, F., (1985) Memoria de la Estación Experimental del Zaidin (CSIC), Granada, Spain.

Sanz Sampelayo, M.R, Muñoz, F.J., Lara, L., Gil, F. and Boza, J. (1987) Effectos del nivel det alimentación, clase de leche y edad en el desarrollo de cabritos de raza Granadina. Investigación Agraria, Producción y Sanidad Animal 2 , 93-103.

Sanz Sampelayo, M.R., Hernández-Clua, O.D., Naranjo, J.A., Gil, F. and Boza, J. (1990) Utilization of goat milk vs. milk replacer for Granadina goat kids. Small Ruminant Research 3, 37-46.

Tacchini, F., Rebora, C., van den Bosch, S., Gascón, A. and Pedrani, M. (2006) Formulation and testing of a wheybased kid goat's milk replacer. Small Ruminant Research 63, 274-281.

Tejón, D., López, C., Piñán, J., de la Fuente, J., Sanz, M., Fernández, A. and Rey, A., (1995) Contribución al estudio de las razas autóctonas de la C.A.M. Evaluación del crecimiento en relación con el sistema de cría de la raza Caprina del Guadarrama. In: XX Jornadas Cientificas de la Sociedad Española de Ovinotecnia y Caprinotecnia, Madrid, Spain, pp. 389-400.

Yan, T., Cook, J.E., Gibb, M.J., Ivings, W.E. and Treacher, T.T. (1993) The effects of quantity and duration of milk feeding on the intake of concentrates and growth of castrated male Saanen kids to slaughter. Animal Production 56, $327-332$. 
Fig. 14.1. Growth curves of goat kids raised under different feeding management systems (Argüello et al., 2004). NS, natural suckling; ALAR, ad libitum artificial rearing; RAR, restricted artificial rearing.

Fig. 14.2. Male (a) and female (b) goat kid feed conversion efficiency (efficiency of conversion of feed mass $(\mathrm{kg})$ into increased body mass $(\mathrm{kg})$ under the ad libitum artificial rearing method (Argüello, 2000).

Fig. 14.3. Principal measurement in kid carcass. G, Width between hips; Th, depth at 6th rib; L, carcass length; $\mathrm{F}$, leg length; $\mathrm{Wr}$, chest width; $\mathrm{B}$, hips perimeter. 
Table 14.1. Correlation matrix for birth and live weights of kids at different ages, as influenced by rearing methods (Argüello et al., 2004).

\begin{tabular}{lllll}
\hline & \multicolumn{3}{l}{ Birth weight } \\
\cline { 2 - 5 } Weight at & NS & ALAR & RAR & NS+ALAR+RAR \\
\hline 7 days & $0.92^{* *}$ & $0.79^{* *}$ & $0.90^{* *}$ & $0.78^{* *}$ \\
14 days & $0.73^{* *}$ & $0.73^{* *}$ & $0.76^{* *}$ & $0.64^{* *}$ \\
21 days & $0.83^{* *}$ & $0.68^{* *}$ & $0.65^{* *}$ & $0.60^{* *}$ \\
28 days & $0.73^{* *}$ & $0.60^{* *}$ & $0.62^{* *}$ & $0.52^{* *}$ \\
35 days & ns & $0.54^{* *}$ & $0.55^{* *}$ & $0.39^{* *}$ \\
\hline
\end{tabular}

NS. Natural suckling. ALAR. Ad libitum artificial rearing. RAR. Restricted artificial rearing. ${ }^{* *} \mathrm{P}<0.01$. ns. No significant differences.

Table 14.2. Carcass yield parameters from kids fed milk or milk replacers (Argüello et al., 2007).

\begin{tabular}{llll} 
& Goat milk & Milk replacers & Standard error \\
\hline Number of animals & 20 & 20 & \\
Live weight slaughter $(\mathrm{kg})$ & 8.31 & 8.10 & 0.33 \\
Empty body weight $(\mathrm{kg})$ & 5.89 & 5.91 & 0.31 \\
Hot carcass weight $(\mathrm{kg})$ & 2.97 & 3.01 & 0.18 \\
Cold carcass weight $(\mathrm{kg})$ & 2.87 & 2.75 & 0.18 \\
Chilling losses $(\%)$ & 3.45 & 3.29 & 0.16 \\
Net carcass yield (\%)* & 50.43 & 50.23 & 0.39 \\
\hline
\end{tabular}

**(Hot Carcass Weight/Empty Body Weight) x 100

Table 14.3. Offal (\% of live weight at slaughter) in kids fed milk or milk replacers (Argüello et al., 2007).

\begin{tabular}{llll}
\hline & Goat milk & Milk replacers & Standard error \\
\hline Blood & 3.89 & 3.27 & 0.14 \\
Skin & 10.18 & 9.93 & 0.01 \\
Feet & 3.85 & 4.09 & 0.10 \\
GI tract (full) & 14.57 & 15.33 & 0.49 \\
GI tract (empty) & 8.95 & 8.99 & 0.15 \\
GI content & 5.62 & 6.34 & 0.41 \\
Liver & 2.95 & 2.73 & 0.01 \\
Urinary bladder & 0.48 & 0.24 & 0.01 \\
Testicle and penis & 0.24 & 0.26 & 0.01 \\
Spleen & 0.22 & 0.21 & 0.01 \\
Right kidney & $0.33^{\mathrm{a}}$ & $0.44^{\mathrm{b}}$ & 0.01 \\
Head & 8.09 & 8.87 & 0.16 \\
Lungs + trachea & 1.72 & 1.69 & 0.01 \\
Heart & 0.75 & 0.68 & 0.01 \\
Thymus & 0.54 & 0.57 & 0.01 \\
\hline
\end{tabular}

Values with different letters on the same row are statistically different.

GI, Gastric intestinal

Table 14.4. Carcass conformation and indexes from kids fed with different diets (Argüello et al., 2007).

\begin{tabular}{llll}
\hline & Goat milk & Milk replacers & Standard error \\
\hline F $(\mathrm{cm})$ & $24.42^{\mathrm{a}}$ & $23.13^{\mathrm{b}}$ & 0.22 \\
$\mathrm{~L}(\mathrm{~cm})$ & $42.71^{\mathrm{a}}$ & $40.48^{\mathrm{b}}$ & 0.04 \\
$\mathrm{G}(\mathrm{cm})$ & 9.88 & 10.20 & 0.13 \\
$\mathrm{Wr}(\mathrm{cm})$ & 11.77 & 10.61 & 0.09 \\
$\mathrm{~B}(\mathrm{~cm})$ & 33.08 & 31.94 & 0.15 \\
Th $(\mathrm{cm})$ & 16.79 & 16.84 & 0.14 \\
$\mathrm{CCW} / \mathrm{L}$ & 93.55 & 93.16 & 0.21 \\
$\mathrm{G} / \mathrm{F}$ & 0.41 & 0.44 & 0.01 \\
$\mathrm{~B} / \mathrm{F}$ & 1.36 & 1.38 & 0.01 \\
\hline
\end{tabular}

Values with different letters on the same row are statistically different. G, width between hips. Th, depth at 6th rib. L, carcass length. F, leg length. Wr, chest width. B, hips perimeter. CCW/L, carcass compactness index. G/F and B/F, long leg compact index. CCW, Cold carcass weights. 
Table 14.5. Contribution of organs and primal cuts to the carcass from kids fed dam milk or milk replacers (Argüello et al., 2007).

\begin{tabular}{llll}
\hline & Goat milk & Milk replacers & Standard error \\
\hline Left kidney & 1.32 & 1.44 & 0.01 \\
Kidney and pelvic fat & 2.95 & 2.62 & 0.14 \\
Tail & 0.50 & 0.39 & 0.01 \\
Shoulder & 20.85 & 20.76 & 0.24 \\
Neck & 10.09 & 10.80 & 0.26 \\
Long leg & 32.93 & 33.86 & 0.39 \\
Flank & 9.64 & 9.54 & 0.20 \\
Ribs & 21.64 & 21.33 & 0.36 \\
By categories & & & \\
Extra & 54.58 & 55.20 & 0.45 \\
First & 20.85 & 20.76 & 0.24 \\
Second & 19.73 & 20.34 & 0.30 \\
\hline
\end{tabular}

Table 14.6. Proportions of fat, bone, muscle and primal cuts ${ }^{1}$ of kids fed goat milk or milk replacers (Argüello et al., 2007).

\begin{tabular}{|c|c|c|c|c|}
\hline & & Goat milk & Milk replacers & Standard error \\
\hline \multirow[t]{6}{*}{ Carcass $^{1}$} & Subcutaneous fat & $4.69^{\mathrm{a}}$ & $3.79^{\mathrm{b}}$ & 0.20 \\
\hline & Intermuscular fat & $3.71^{\mathrm{a}}$ & $2.56^{\mathrm{b}}$ & 0.22 \\
\hline & Total fat & $11.35^{\mathrm{a}}$ & $8.97^{b}$ & 0.46 \\
\hline & Bone & 29.43 & 30.32 & 0.45 \\
\hline & Muscle & 55.03 & 55.70 & 0.46 \\
\hline & Losses & 1.08 & 2.31 & 0.26 \\
\hline \multirow[t]{6}{*}{ Shoulder } & Subcutaneous fat & 3.20 & 2.52 & 0.20 \\
\hline & Intermuscular fat & $2.67^{\mathrm{a}}$ & $1.69^{\mathrm{b}}$ & 0.24 \\
\hline & Total fat & $5.87^{\mathrm{a}}$ & $4.21^{\mathrm{b}}$ & 0.32 \\
\hline & Bone & 30.87 & 31.69 & 0.46 \\
\hline & Muscle & 62.09 & 61.58 & 0.37 \\
\hline & Losses & 0.38 & 1.42 & 0.23 \\
\hline \multirow[t]{6}{*}{ Neck } & Subcutaneous fat & 6.89 & 6.43 & 0.51 \\
\hline & Intermuscular fat & 4.22 & 3.15 & 0.44 \\
\hline & Total fat & 11.11 & 9.58 & 0.55 \\
\hline & Bone & 28.53 & 29.30 & 0.66 \\
\hline & Muscle & 55.18 & 50.67 & 1.08 \\
\hline & Losses & 4.09 & 8.57 & 1.12 \\
\hline \multirow[t]{6}{*}{ Long leg } & Subcutaneous fat & 4.55 & 3.59 & 0.31 \\
\hline & Intermuscular fat & $3.64 \mathrm{a}$ & $2.46 \mathrm{~b}$ & 0.23 \\
\hline & Total fat & $8.19 \mathrm{a}$ & $6.05 b$ & 0.41 \\
\hline & Bone & 30.16 & 29.94 & 0.46 \\
\hline & Muscle & 60.26 & 61.93 & 0.40 \\
\hline & Losses & 0.49 & 1.03 & 0.13 \\
\hline \multirow[t]{6}{*}{ Flanks } & Subcutaneous fat & 6.49 & 5.55 & 0.43 \\
\hline & Intermuscular fat & $6.95 \mathrm{a}$ & $4.70 \mathrm{~b}$ & 0.57 \\
\hline & Total fat & $13.44 \mathrm{a}$ & $10.25 b$ & 0.71 \\
\hline & Bone & 29.68 & 31.85 & 0.99 \\
\hline & Muscle & 54.19 & 54.34 & 1.01 \\
\hline & Losses & 0.47 & 0.43 & 0.12 \\
\hline \multirow[t]{6}{*}{ Ribs } & Subcutaneous fat & $5.44 \mathrm{a}$ & $3.88 \mathrm{~b}$ & 0.31 \\
\hline & Intermuscular fat & $3.96 \mathrm{a}$ & $2.66 \mathrm{~b}$ & 0.32 \\
\hline & Total fat & $9.40 \mathrm{a}$ & $6.54 \mathrm{~b}$ & 0.49 \\
\hline & Bone & 33.80 & 34.93 & 0.75 \\
\hline & Muscle & 53.18 & 52.97 & 0.63 \\
\hline & Losses & 1.61 & 3.06 & 0.30 \\
\hline
\end{tabular}

${ }^{1}$, Proportions in carcass weight, ${ }^{2}$, Proportions in joint weight.

Values with different letters on the same row are statistically different. 
Table 14.7. Effects of diet on M. Longissimus dorsi attributes in kids fed milk or milk replacers (Argüello et al., 2005)

\begin{tabular}{lll} 
& Goat milk & Milk replacers \\
\hline $\mathrm{pH}^{1}$ & $6.08 \pm 0.24$ & $6.30 \pm 0.31$ \\
$\mathrm{pH}^{2}$ & $5.59 \pm 0.18$ & $5.73 \pm 0.01$ \\
$\mathrm{~L}^{1}$ & $50.07 \pm 3.92$ & $49.53 \pm 3.00$ \\
$\mathrm{~L}^{2}$ & $56.57 \pm 4.82$ & $56.93 \pm 3.96$ \\
Chroma $^{1}$ & $9.08 \pm 1.72$ & $10.45 \pm 2.43$ \\
Chroma $^{2}$ & $13.76 \pm 3.99^{\mathrm{a}}$ & $16.11 \pm 5.69^{\mathrm{b}}$ \\
Hue $^{1}$ & $26.79 \pm 12.25$ & $29.75 \pm 8.94$ \\
Hue $^{2}$ & $43.99 \pm 7.67$ & $42.08 \pm 6.09$ \\
SF $(\mathrm{N})$ & $50.07 \pm 14.93$ & $55.71 \pm 13.41$ \\
WHC $(\mathrm{g})$ & $0.66 \pm 0.11 \mathrm{a}$ & $0.46 \pm 0.10 \mathrm{~b}$ \\
Moisture $(\%)$ & $78.21 \pm 0.38$ & $78.40 \pm 1.20$ \\
Protein $(\%)$ & $18.67 \pm 0.72$ & $19.05 \pm 1.74$ \\
Fat $(\%)$ & $1.26 \pm 0.41$ & $0.96 \pm 0.44$ \\
Ash $(\%)$ & $1.15 \pm 0.09$ & $1.12 \pm 0.05$ \\
Collagen $(\%)$ & $0.60 \pm 0.13$ & $0.46 \pm 0.16$ \\
Coll. Sol. $(\%)$ & $70.49 \pm 8.47$ & $85.62 \pm 15.84$ \\
$\%$ Type I & $24.00 \pm 11.43$ & $32.91 \pm 22.67$ \\
$\%$ Type IIA & $46.00 \pm 10.70$ & $35.50 \pm 15.68$ \\
$\%$ Type IIB & $30.00 \pm 4.00$ & $31.85 \pm 19.30$ \\
Type I $\left(\mu^{2}\right)$ & $484.27 \pm 151.88$ & $389.10 \pm 123.79$ \\
Type IIA $\left(\mu^{2}\right)$ & $541.23 \pm 224.02$ & $354.16 \pm 164.43$ \\
Type IIB $\left(\mu^{2}\right)$ & $472.49 \pm 166.04$ & $367.02 \pm 86.79$ \\
\hline
\end{tabular}

${ }^{1}$. At slaughter; ${ }^{2}$. After chilling; L: lightness; SF: Shear force; WHC: Water holding capacity; Coll. Sol.: Collagen solubility. Data shown in mean \pm standard deviation.

Values with different letters on the same row are statistically different.

Table 14.8. Effects of diet on M. Triceps brachii attributes in kids fed milk or milk replacers (Argüello et al., 2005)

\begin{tabular}{|c|c|c|}
\hline & Goat milk & Milk replacers \\
\hline $\mathrm{pH}^{1}$ & $6.34 \pm 0.21$ & $6.53 \pm 0.27$ \\
\hline $\mathrm{pH}^{2}$ & $5.82 \pm 0.10$ & $5.80 \pm 0.14$ \\
\hline $\mathrm{L}^{1}$ & $53.08 \pm 4.61$ & $53.60 \pm 3.95$ \\
\hline $\mathrm{L}^{2}$ & $56.33 \pm 3.08$ & $55.47 \pm 4.98$ \\
\hline Chroma $^{1}$ & $12.50 \pm 3.36$ & $11.03 \pm 1.41$ \\
\hline Chroma $^{2}$ & $13.99 \pm 2.46^{\mathrm{a}}$ & $15.26 \pm 1.76^{b}$ \\
\hline Hue $^{1}$ & $31.34 \pm 8.93$ & $31.87 \pm 6.74$ \\
\hline Hue $^{2}$ & $39.82 \pm 7.83$ & $38.29 \pm 10.36$ \\
\hline $\mathrm{SF}(\mathrm{N})$ & $83.18 \pm 8.64 a$ & $88.40 \pm 6.85 b$ \\
\hline WHC (g) & $0.41 \pm 0.08 \mathrm{a}$ & $0.33 \pm 0.07 \mathrm{~b}$ \\
\hline Moisture (\%) & $78.38 \pm 1.41$ & $78.55 \pm 0.40$ \\
\hline Protein $(\%)$ & $17.54 \pm 2.07$ & $18.53 \pm 0.69$ \\
\hline Fat $(\%)$ & $0.84 \pm 0.22$ & $1.08 \pm 0.51$ \\
\hline Ash (\%) & $1.08 \pm 0.07$ & $1.16 \pm 0.07$ \\
\hline Collagen (\%) & $0.49 \pm 0.06$ & $0.40 \pm 0.06$ \\
\hline Coll. Sol. (\%) & $83.04 \pm 3.04$ & $83.09 \pm 12.14$ \\
\hline \% Type I & $29.49 \pm 8.63$ & $17.53 \pm 12.72$ \\
\hline \% Type IIA & $40.13 \pm 9.90$ & $36.18 \pm 19.26$ \\
\hline \% Type IIB & $30.37 \pm 6.51$ & $46.28 \pm 11.55$ \\
\hline Type I $\left(\mu^{2}\right)$ & $596.22 \pm 126.13$ & $570.73 \pm 134.55$ \\
\hline Type IIA $\left(\mu^{2}\right)$ & $707.24 \pm 238.84$ & $636.02 \pm 123.01$ \\
\hline Type IIB $\left(\mu^{2}\right)$ & $678.77 \pm 254.48$ & $640.60 \pm 142.63$ \\
\hline
\end{tabular}

${ }^{1}$. At slaughter. ${ }^{2}$. After chilling. L: lightness. SF: Shear force. WHC: Water holding capacity. Coll. Sol: Collagen solubility. Data shown in mean \pm standard deviation.

Values with different letters on the same row are statistically different. 
Table 14.9. Effects of diet on M. Semimembranosus attributes in kids fed milk or milk replacers (Argüello et al., 2005)

\begin{tabular}{|c|c|c|}
\hline & Goat milk & Milk replacers \\
\hline $\mathrm{pH}^{1}$ & $6.09 \pm 0.27$ & $6.39 \pm 0.22$ \\
\hline $\mathrm{pH}^{2}$ & $5.58 \pm 0.04$ & $5.64 \pm 0.07$ \\
\hline $\mathrm{L}^{1}$ & $47.13 \pm 17.32$ & $54.43 \pm 3.11$ \\
\hline $\mathrm{L}^{2}$ & $53.61 \pm 5.47$ & $54.49 \pm 2.11$ \\
\hline Chroma $^{1}$ & $9.73 \pm 2.34$ & $11.87 \pm 2.61$ \\
\hline Chroma $^{2}$ & $12.43 \pm 2.24^{\mathrm{a}}$ & $14.46 \pm 3.64^{b}$ \\
\hline Hue ${ }^{1}$ & $34.57 \pm 13.71$ & $32.28 \pm 7.01$ \\
\hline $\mathrm{Hue}^{2}$ & $44.93 \pm 12.01$ & $41.28 \pm 6.62$ \\
\hline $\mathrm{SF}(\mathrm{N})$ & $32.64 \pm 11.87^{\mathrm{a}}$ & $43.67 \pm 6.24^{b}$ \\
\hline WHC (g) & $0.72 \pm 0.16^{\mathrm{a}}$ & $0.60 \pm 0.15^{b}$ \\
\hline Moisture (\%) & $78.46 \pm 0.50$ & $78.51 \pm 0.88$ \\
\hline Protein $(\%)$ & $18.20 \pm 0.99$ & $18.10 \pm 1.65$ \\
\hline Fat $(\%)$ & $0.91 \pm 0.34$ & $1.10 \pm 0.51$ \\
\hline Ash (\%) & $1.18 \pm 0.06$ & $1.18 \pm 0.09$ \\
\hline Collagen (\%) & $0.46 \pm 0.05$ & $0.42 \pm 0.09$ \\
\hline Coll. Sol. (\%) & $81.52 \pm 10.48$ & $74.69 \pm 8.77$ \\
\hline \% Type I & $9.75 \pm 5.68$ & $31.40 \pm 25.65$ \\
\hline$\%$ Type IIA & $84.25 \pm 4.27$ & $13.83 \pm 9.24$ \\
\hline$\%$ Type IIB & $6.00 \pm 1.82$ & $54.77 \pm 34.61$ \\
\hline Type I $\left(\mu^{2}\right)$ & $508.45 \pm 93.47$ & $528.04 \pm 106.56$ \\
\hline Type IIA $\left(\mu^{2}\right)$ & $564.45 \pm 198.00$ & $602.65 \pm 138.86$ \\
\hline Type IIB $\left(\mu^{2}\right)$ & $565.55 \pm 146.38$ & $586.34 \pm 129.95$ \\
\hline
\end{tabular}

${ }^{1}$. At slaughter. ${ }^{2}$. After chilling. L: lightness. SF: Shear force. WHC: Water holding capacity. Coll. Sol: Collagen solubility. Data shown in mean \pm standard deviation.

Values with different letters on the same row are statistically different. 